\title{
Komunikasi Antar Pribadi Orangtua-Anak Pasca Perceraian
}

\author{
Ferren Alwinda, Yugih Setyanto \\ ferren.setiawan@gmail.com,yugihs@fikom.untar.ac.id
}

Fakultas Ilmu Komunikasi Universitas Tarumanagara

\begin{abstract}
Humans are social beings who are unable to live alone. The first environment for every human being when he is born into the world is family. Communication that occurs in the family is interpersonal communication. An ideal family would have dreams of having a harmonious life. But in reality, not all families can feel it. There are several factors that can cause this disharmony to lead to divorce. Every divorce that occurs, of course, has its own impact, especially for married couples who already have children. The impact of parental divorce will certainly form a different character for the child, especially for those who are growing up in their teens. The impact of divorce will also change the interpersonal communication that occurs between fathers and mothers and their children. The purpose of this study was to analyze the application of interpersonal communication in the family to children after their parents' divorce. This study uses a qualitative research approach with descriptive research methods. In this study, researchers interviewed a single father with his teenage children, a single mother with her child and a psychologist. The results of this study indicate that divorce has an impact on changing the interpersonal communication relationship between children and parents, which initially becomes tenuous, but not with parents who still live at home with their children.
\end{abstract}

Keywords: divorce, impact, interpersonal communication, teenage

\begin{abstract}
Abstrak
Manusia merupakan makhluk sosial yang tidak mampu hidup seorang diri. Lingkungan pertama bagi setiap manusia ketika lahir ke dunia adalah keluarga. Komunikasi yang terjadi di dalam keluarga ialah komunikasi antarpribadi. Sebuah keluarga yang ideal tentu memiliki impian untuk memiliki kehidupan yang harmonis. Namun pada kenyataannya, tidak semua keluarga dapat merasakannya. Ada beberapa faktor yang dapat menimbulkan ketidakharmonisan tersebut sehingga menimbulkan perceraian. Perceraian yang terjadi memiliki dampak tersendiri terutama bagi pasangan suami-istri yang sudah memiliki anak. Dampak dari perceraian orang tua dapat membentuk karakter yang berbeda terhadap anak tersebut, terutama bagi yang sedang tumbuh di usia remaja. Dampak dari perceraian juga akan mengubah komunikasi antarpribadi yang terjadi antara ayah dan ibu serta anak. Penelitian ini dilakukan untuk menganalisis penerapan komunikasi antarpribadi di dalam keluarga terhadap anak pasca perceraian orang tua. Penelitian ini menggunakan pendekatan penelitian kualitatif dengan metode penelitian deskriptif. Pada penelitian ini, peneliti mewawancari seorang ayah tunggal dengan anak remajanya, seorang ibu tunggal dengan anaknya, dan psikolog. Hasil dari penelitian ini menunjukkan bahwa perceraian berdampak pada perubahan hubungan komunikasi antarpribadi antara anak dengan orang tua, yang pada mulanya hangat menjadi renggang. Namun hal ini tidak berlaku bagi hubungan komunikasi orang tua yang masih tinggal serumah dengan anaknya.
\end{abstract}

Kata Kunci: dampak, komunikasi antarpribadi, perceraian, remaja 


\section{Pendahuluan}

Manusia pada hakekatnya ialah makhluk sosial yang sudah pasti tidak akan dapat bertahan apabila hidup hanya seorang diri. Sejak lahir, manusia sudah pasti akan memerlukan bantuan orang lain. Lingkungan pertama bagi setiap manusia ketika lahir ke dunia adalah keluarga. Setiap keluarga pasti memiliki cara berkomunikasinya masing-masing dan sudah pasti akan berkomunikasi. Komunikasi yang terjadi salah satunya adalah komunikasi antarpribadi yang definisinya menurut Joseph A. Devito (2001) terbagi menjadi dua klasifikasi yaitu definisi berdasarkan hubungan diadik dan pengembangan (development). Dilihat dari sisi hubungan diadik, komunikasi antarpribadi didefinisikan sebagai komunikasi yang berlangsung antar dua orang yang mempunyai hubungan yang mantap dan jelas, seperti layaknya hubungan anak dan ayah. Sementara jika dilihat dari sisi pengembangan suatu hubungan, komunikasi antarpribadi diartikan sebagai bentuk ideal terakhir dari perkembangan suatu hubungan komunikasi nonantarpribadi (Devito, 2001).

Dikutip dari jurnal yang berjudul "Studi Komunikasi Antarpribadi Anak Dengan Orang Tua Tiri” yang ditulis oleh Chaterine Setiawan dan Suzy Azeharie, sebagai mahluk sosial, manusia selalu melakukan proses komunikasi satu dengan yang lain secara sengaja ataupun tidak disengaja yang bertujuan untuk memenuhi kebutuhan fisik ataupun jasmani. Komunikasi juga terjadi dalam keluarga karena keluarga adalah tempat pertama bagi seseorang untuk berkomunikasi dalam kehidupan sehari-hari (Setiawan dan Azeharie, 2017).

Di dalam sebuah keluarga yang ideal yang terdiri dari ayah, ibu, dan anakanak pasti akan terbangun suatu ikatan komunikasi. Keluarga yang harmonis pasti akan memiliki sistem komunikasi yang baik, contohnya seperti cara berkomunikasi anak ke orang tua. Ketika anak melakukan kegiatan komunikasi kepada orang tuanya tentu akan menggunakan bahasa dan nada yang lebih sopan. Begitupun orang tua kepada anaknya pasti akan berkomunikasi secara halus. Namun tidak semua keluarga mampu membangun komunikasi keluarga dengan baik. Secara umum, orang tua yang terdiri dari ayah dan ibu merupakan sebuah panutan utama atau bisa dibilang sebagai contoh teladan bagi anak-anaknya. Seorang anak ketika lahir ke dunia, dapat dipastikan bahwa ia tidak akan mengerti mengenai dunia ini dengan sendirinya. Maka daripada itu, ia akan belajar dengan cara meniru segala hal yang dilakukan oleh orang tuanya. Namun tidak semua anak bisa merasakannya, terutama bagi anak yang berada di situasi orang tua yang bercerai.

Sebagai orang tua, segala keputusan besar yang diambil tentu akan memiliki dampaknya tersendiri terutama bagi mereka yang sudah memiliki anak. Mulai dari psikis anak, cara membagi waktu, hingga munculnya sikap egoisme dalam diri. Namun fenomena yang sering terjadi di kasus perceraian justru menimbulkan dampak yang buruk terutama karna faktor kurangnya komunikasi. Hal ini biasanya tejadi ketika salah satu orang tua, baik ibu maupun ayah yang pergi meninggalkan rumah dikarenakan sudah sah bercerai dari pasangannya. Ketika salah satu orang tua pergi dari rumah, tentu komunikasi menjadi bermasalah.

Melihat kenyataan yang ada terutama yang sering terjadi di masyarakat, dalam hal ini penulis melakukan observasi dengan lingkungan sekitar, maka membuat penulis menjadi tertarik untuk meneliti fenomena ini dengan berfokus pada bagaimana penerapan komunikasi antarpribadi yang terjadi di dalam keluarga terhadap anak pasca perceraian kedua orang tuanya. Namun pada penelitian ini, peneliti akan lebih berfokus pada komunikasi antarpribadi di dalam keluarga antara 
orang tua tunggal dengan anaknya yang sedang berada di usia remaja. Adapun tujuan yang ingin dicapai peneliti dalam penelitian ini adalah untuk menganalisis penerapan komunikasi antar pribadi di dalam keluarga terhadap anak pasca perceraian orang tua.

\section{Metode Penelitian}

Pada penelitian ini, peneliti menggunakan metode penelitian pendekatan kualitatif. Menurut Sugiyono (2009), metode penelitian kualitatif adalah suatu usaha atau suatu penelitian yang digunakan dengan manfaat untuk mengetahui, menyelidiki, memahami maupun menjelaskan suatu peristiwa yang terjadi akibat adanya pengaruh sosial yang tidak mampu untuk dijelaskan ataupun dipahami melalui metode penelitian kuantitatif. Secara umum, metode penelitian kualitatif memiliki makna yaitu suatu jenis penelitian dalam bidang ilmu sosial dengan mengumpulkan data non-numerik melalui suatu usaha untuk mengartikan sebuah makna dari sebuah data sehingga hasilnya dapat digunakan sebagai pemahaman kehidupan sosial melalui studi populasi.

Metode penelitian yang penulis gunakan untuk penelitian ini ialah metode penelitian deskriptif kualitatif. Menurut Nazir (2003) dalam buku Contoh Metode Penelitian, metode deskriptif merupakan suatu metode dalam meneliti status sekelompok manusia, suatu objek, suatu set kondisi, suatu sistem pemikiran ataupun suatu kelas peristiwa pada masa sekarang. Tujuan peneliti menggunakan metode deskriptif dalam penelitian ini adalah untuk membuat suatu penjelasan, gambaran, atau pemahaman secara sistematis, faktual dan akurat.

Adapun teknik pengumpulan data yang digunakan untuk menunjang informasi pada penelitian ini, penulis menggunakan beberapa metode pengumpulan data antara lain pengamatan (observation), wawancara (interview) dan dokumentasi. Narasumber yang peneliti gunakan sebagai subjek penelitian adalah seorang ayah tunggal yang berusia 57 tahun berinisial AS yang sudah bercerai dengan istrinya sejak 7 tahun lalu, anak remaja laki-lakinya, inisial W berusia 17 tahun; seorang ibu tunggal inisial DS (52 tahun) dan anak perempuan remajanya berinisial HT (20 tahun); serta seorang pakar psikologi bernama Debora Basaria (Olla).

\section{Hasil Temuan dan Diskusi}

Dalam penelitian ini, peneliti mewawancari seorang ayah tunggal yang bernama AS dan anaknya, W. Sejak 7 tahun lalu, AS (57 tahun) harus bercerai dengan istrinya, MI (44 tahun) dikarenakan adanya perbedaan pendapat dalam keyakinan beragama sehingga mengakibatkan MI menggugat cerai. Dalam masa pernikahannya, AS dan MI dikaruniai seorang putra dan seorang putri, W dan P. W pada saat diwawacara oleh peneliti berusia 17 tahun sedangkan P berusia 11 tahun.

Perceraian bermula ketika AS tengah membantu kakak laki-lakinya yang pada saat itu meminta bantuannya untuk membawanya ke sebuah tempat ibadah. Namun karena hal tersebut, membuat istri AS, MI, menjadi marah dikarenakan tidak menyukai suaminya untuk datang ke tempat ibadah agama lain selain agama yang dianutnya. Pada akhinya, MI mengetahui bahwa AS sudah berpindah keyakinan dengan memeluk agama yang dianut oleh kakaknya, dengan demikian membuat MI merasa tidak terima dan menggugat cerai. Pada awalnya, hak asuh anak jatuh kepada 
MI, namun pada akhirnya jatuh kembali ke AS dikarenakan muncul suatu peristiwa lain.

Selanjutnya peneliti mewawancarai seorang ibu tunggal yang bernama DS (52 tahun) dan anak perempuan remajanya yang bernama HT (20 tahun). DS harus bercerai dengan suaminya dikarenakan perbedaan pendapat yang sudah terjadi sejak lama dan tidak dapat terselesaikan. Perceraian yang dialami oleh DS sudah terjadi sejak 2 tahun silam. Dari hasil pernikahan tersebut, DS dikaruniai 2 orang yaitu RT (25 tahun) dan HT. Pada sesi wawancara, penulis menanyakan seputar hubungan komunikasi antarpribadi yang diterapkan oleh DS terhadap anak-anaknya terutama pada HT yang pada saat ini tengah berada di usia remaja akhir.

Berdasarkan penuturan dari pakar psikolog, Debora Basaria atau Olla melalui wawancara dengan penulis, menuturkan "perceraian di dalam keluarga di mana keluarga tersebut apalagi sudah memiliki anak, itu sedikit banyak bisa mempengaruhi pertumbuhan dan perkembang anak itu sendiri." Penerapan komunikasi antarpribadi yang terjadi di dalam sebuah keluarga yang mengalami perceraian sangat berbeda ketika pasangan suami-istri tersebut masih bersama di dalam ikatan pernikahan. Bagi pasangan suami-istri yang sudah memiliki anak, resiko dan dampak dari perceraian terhadap anak mereka tentu sangat besar. Perbedaan kondisi yang pada awalnya normal dengan kedua orang tua yang utuh, secara terpaksa akan berubah ketika orang tua bercerai. Maka dari itu akan mengubah intensitas komunikasi hingga karakter dari anak itu sendiri.

\section{Penyebab Perceraian}

Perceraian sendiri tentu memiliki banyak penyebabnya. Seperti permasalahan ekonomi, perbedaan pendapat, sudah tidak adanya rasa toleransi, perselingkuhan, KDRT (kekerasan dalam rumah tangga), dan masih banyak penyebab lainnya. Psikolog, Olla menjelaskan bahwa penyebab dari perceraian ada berbagai hal, namun yang pada umum terjadi adalah sudah tidak adanya toleransi, penyesuaian diri, maupun kemampuan dalam pemecahan masalah, "orang itu kan bercerai karena dalam artian sudah tidak bisa lagi menyesuaikan, toleransi, maupun problem solvingnya sudah tidak bisa. Itu ada kondisi-kondisi tertentu."

Mengutip dari jurnal yang ditulis oleh Armansyah Matondang (2014) dengan judul "Faktor-faktor yang Mengakibatkan Perceraian dalam Perkawinan", mengatakan bahwa perbedaan pendapat, pertengkaran, percekcokan, perselisihan yang terus menerus menyebabkan hilangnya rasa cinta dan kasih sayang. Pertengkaran menyebabkan bersemainya rasa benci dan buruk sangka terhadap pasangan. Pertengkaran yang meluap-luap menyebabkan hilangnya rasa percaya dan terus memicu perceraian. Penyebab perceraian juga dipicu maraknya pernikahan di bawah umur. Pernikahan di bawah umur membuat mereka belum siap mengatasi pernik-pernik pertikaian yang mereka jumpai.

\section{Dampak Perceraian Bagi Anak}

Apabila salah satu orang tua baik ayah maupun ibu memutuskan keluar dari rumah pasca perceraian, hal ini mengakibatkan berkurangnya intensitas komunikasi antarpribadi yang terjadi antara salah satu pasangan yang keluar dari rumah dengan pasangan yang tetap tinggal di dalam rumah tersebut. Perbedaan jarak, tempat tinggal, bahkan waktu bisa menjadi faktor berkurangnya intensitas komunikasi.

Hal ini selaras dengan jawaban dari $\mathrm{W}$, yang mengatakan bahwa dirinya merasa kehilangan sosok orang tua. Ia melihat ketika teman-temannya dapat 
dijemput di sekolah oleh kedua orang tuanya secara lengkap, ia tidak dapat merasakan hal tersebut. Perubahan pola perilaku ia rasakan dan sadari. HT pun merasakan adanya dampak dari perceraian dari kedua orang tuanya. Ia mengatakan bahwa ketika orang tuanya sudah bercerai, ia merasakan sebuah kesedihan dikarenakan sudah tidak ada lagi panutan bagi dirinya dalam hal mencari pasangan hidup di kemudian hari. HT juga menuturkan bahwa dampak dari perceraian sendiri membuat ia menjadi merasa sepi ketika berada di rumah.

Mengutip dari jurnal Family, Teenagers Self Concept from Divorce yang ditulis Lucy Pujasari Supratman (2015) yang berjudul "Konsep Diri Remaja Dari Keluarga Bercerai", dikatakan bahwa keluarga bercerai dapat membuat anak tidak mampu melakukan proses identifikasi pada orangtua. Proses tersebut adalah saat dimana ayah dan ibu tidak dapat berperan sebagai orangtua yang dapat dijadikan cermin berperilaku. Ketimpangan keberadaan orangtua yang menjalankan peran ganda sebagai ayah atau ibu tunggal hanya didapatkan dari salah satu pihak saja.

\section{Komunikasi Antara Orang Tua dengan Anak Pasca Perceraian}

Ketika ditanya perihal komunikasi yang terjadi saat ini antara $\mathrm{W}$ dengan ibunya yang tinggal tidak serumah, ia menjawab seperti tidak begitu mempedulikannya. Namun hal sebaliknya yang ditemukan ketika ditanya perihal ayahnya, $\mathrm{W}$ mengatakan bahwa ia memiliki rasa peduli bahkan menyatakan bahwa ayahnya adalah orang tua terbaik bagi dirinya. Begitupun dengan HT, berdasarkan hasil wawancara penulis dengan responden, ia mengatakan bahwa sudah jarang sekali berkomunikasi dengan ayahnya dikarenakan tidak adanya respon balik. Ini mengakibatkan ia menjadi lebih cuek terhadap ayahnya. Namun hal yang sebaliknya pada hubungan HT dan ibunya, DS, ia mengatakan bahwa ia cukup mendengarkan mengenai perkataan ataupun nasihat dari ibunya.

Maka dari itu, penulis dapat melihat bahwa adanya perbedaan sikap dan respon yang dilakukan oleh anak remaja terhadap kedua orang tuanya. Orang tua yang berusaha untuk tetap perduli dengan anaknya walaupun sudah menjadi orang tua tunggal, perhatiannya akan tetap terasa oleh anak tersebut sehingga memunculkan respon yang baik, begitupun sebaliknya.

\section{Komunikasi Antarpribadi Orang Tua Tunggal dengan Anak Remajanya Pasca Perceraian}

Komunikasi yang terjalin antara orang tua, baik ayah maupun ibu, sudah sepatutnya diberikan kepada anaknya dalam bentuk kasih sayang. Namun apabila orang tua memutuskan untuk bercerai, maka komunikasi terhadap pihak yang keluar dari rumah akan berkurang. Narasumber W mengatakan bahwa pasca perceraian, ia tidak lagi mengetahui informasi seputar ibunya. Ia tidak tahu mengenai ibunya setelah tidak lagi tinggal bersama ibunya. Namun ketika ia masih tinggal bersama istrinya MI, AS sebagai ayah W, tetap ingin mengetahui seputar perkembangan dari anak-anaknya, menjaga komunikasi dan tetap bertanggung jawab atas segala kebutuhan yang diperlukan oleh $\mathrm{W}$ dan adiknya.

Namun pada saat $\mathrm{W}$ pindah untuk tinggal bersama ayahnya, ia melihat ada upaya yang dilakukan oleh ayahnya untuk dekat dengannya bahkan mau belajar memahami apa yang $\mathrm{W}$ rasakan dan alami. Hal sederhana berupa perhatian yang diberikan oleh ayahnya setiap hari, membuat $\mathrm{W}$ merasa bahwa perilaku yang dilakukannya adalah salah, karena ketika ia sudah pindah untuk tinggal bersama ayahnya, ia tetap tidak acuh bahkan terkesan tidak peduli hingga sempat membuat 
ayahnya menangis. Maka dari itu, W mengubah sikapnya tersebut. Hal ini dikarenakan, $\mathrm{W}$ merasa bawa perhatian yang ayahnya berikan adalah hal luar biasa yang dapat ia rasakan dan nikmati. Ia menyadari bahwa peran orang tua tunggal yang dijalani oleh ayahnya adalah hal yang menakjubkan baginya. Ia mengatakan, kini hubungannya dengan ayahnya sudah lebih santai layaknya sebagai teman namun masih ada batas-batas normal, dalam hal ini kesopanan.

Dalam hubungan komunikasi antarpribadi yang terjadi antara DS dan HT, mereka sering melakukan berbagi cerita maupun menanyakan pendapat satu sama lain. Selain itu, dalam hasil wawancara, DS menuturkan bahwa ia selalu menanamkan prinsip hidup yang baik kepada anak-anaknya yaitu taat dengan Tuhan dan bersikap jujur.

\section{Peran Orang Tua Tunggal Dalam Pengasuhan dan Tumbuh Kembang Anak Remajanya}

Peran ganda yang dialami orang tua tunggal dirasakan pula oleh AS. Ia menjelaskan bahwa peran gandanya, bukan hanya menjadi sosok ayah melainkan juga harus menjadi seorang ibu bagi kedua anaknya. AS menjelaskan bahwa kegiatan yang dilakukannya sehari-hari kepada anak-anaknya ialah seperti membangunkan setiap pagi untuk sekolah, membantu menyiapkan segala keperluan yang anaknya butuhkan, hingga sekedar menanyakan kegiatan sekolah yang tengah dijalani oleh anak-anaknya.

AS mengakui bahwa peran orang tua tunggal tidaklah mudah. Ia harus mampu membagi waktu kerjanya guna mencari nafkah dan waktu untuk kedua anaknya. AS menyadari bahwa perceraian yang dialaminya, membawa dampak besar bagi tumbuh kembang anak-anaknya. Hal serupa juga dirasakan oleh DS selaku ibu tunggal bagi kedua anaknya. Dalam menjalankan perannya sebagai orang tua tunggal, DS diwajibkan harus mampu mendidik anak-anaknya sekaligus mencari nafkah untuk kehidupan keluarganya.

\section{Membangun Hubungan Komunikasi Interpersonal Antara Orang Tua Tunggal dengan Anak Remajanya}

Dalam membangun hubungan yang baik dengan anak-anaknya, terutama $\mathrm{W}$, AS menempatkan diri bukan hanya sebagai orang tua namun juga sebagai seorang teman. Guna menciptakan suasana rumah yang hangat, setiap hari AS pasti akan mengajak berbincang dengan kedua anaknya walaupun hanya sekedar menanyakan kegiatan mereka ketika ia sedang bekerja. AS menjelaskan bahwa ia sering memberikan masukan kepada $\mathrm{W}$ mengenai pergaulan remaja di masa sekarang. Menurut AS, pergaulan remaja zaman sekarang dapat terkategorikan lebih kejam, di mana semua hal dapat diakses dengan mudah. Walau demikian, hal ini tidak membuat $\mathrm{W}$ menjadi tertekan.

Begitupun dengan yang diterapkan oleh DS kepada kedua anaknya. Ia selalu memberikan arahan bahwa harus berhati-hati dalam hidup dikarenakan kondisi pergaulan yang semakin kacau. Selain itu DS juga sering mengingatkan anakanaknya untuk tetap di jalan yang baik dan bersifat jujur.

\section{Hubungan Interpersonal Ayah dan Ibu Dalam Mendidik Anak-anaknya Pasca Perceraian}

Psikolog, Debora Basaria, menjelaskan tindakan yang paling tepat yang dilakukan oleh pasangan suami-istri yang sudah bercerai adalah tetap menjalin 
komunikasi, dalam hal ini silahturahmi. Hal ini sangat berguna, terutama bagi mereka yang sudah memiliki anak. Hubungan komunikasi yang tetap terjalin dengan baik, tentu juga memiliki dampak yang baik untuk anak mereka, walaupun tentu saja perceraian memiliki dampak negatifnya tersendiri. Setidaknya bisa meminimalisir tingkat depresi dari anak tersebut dikarenakan tidak berkurangnya kasih sayang dari kedua orang tuanya.

\section{Simpulan}

Lingkungan pertama bagi seorang anak ialah keluarga. Apabila orang tua mampu menciptakan kondisi yang baik dan nyaman bagi anak-anaknya maka tumbuh kembang bagi anak tersebut juga akan baik. Selanjutnya anak remaja yang menjadi korban perceraian memiliki sifat yang lebih sensitif apabila membahas seputar keluarga. Hal ini dikarenakan ia kerap membandingkan dirinya dengan teman-temannya yang memiliki keadaan keluarga dengan orang tua yang utuh sehingga ia merasa kekurangan kasih sayang dari kedua orang tuanya.

Penelitian ini juga menemukan adanya perbedaan komunikasi antarpribadi yang terjalin antara orang tua tunggal yang tidak tinggal serumah dengan anaknya dan orang tua tunggal yang tinggal serumah dengan anaknya. Orang tua tunggal yang tinggal serumah dengan anaknya memiliki kesempatan yang lebih baik untuk mengasuh dan mendidik anak-anaknya. Hal ini karena orang tua melihat secara langsung tumbuh kembang dari anak-anaknya sehingga mampu mengarahkan ke arah yang lebih baik.

\section{Ucapan Terima Kasih}

Peneliti hendak menyampaikan terima kasih kepada Fakultas Ilmu Komunikasi Tarumanagara, dosen pembimbing, seluruh narasumber dan rekan-rekan yang telah memberikan dukungan sehingga penelitian ini dapat diselesaikan dengan baik.

\section{Daftar Pustaka}

DeVito, Joseph A. (2001). The Interpersonal Communication Book. London: Longman.

Matondang, A. (2014). Faktor-faktor yang mengakibatkan perceraian dalam perkawinan. JPPUMA Jurnal Ilmu Pemerintahan dan Sosial Politik Universitas Medan Area, 2(2), 141-150.

Nazir, Muhammad. (2003). Metode Penelitian. Jakarta: Ghalia Indonesia.

Setiawan, C., \& Azeharie, S. (2017). Studi Komunikasi Antarpribadi Anak Dengan Orang Tua Tiri. Jurnal Komunikasi, 9(1), 74-80.

Sugiyono. (2009). Metode Penelitian Pendidikan, Pendekatan Kuantitatif, Kualitatif, dan $R \& D$. Bandung: Alfa Beta.

Supratman, Lucy Pujasari. (2015). Konsep diri remaja dari keluarga bercerai. Jurnal Penelitian Komunikasi Vol, 18(2), 129-140.

Undang-undang Perkawinan: Undang-undang Republik Indonesia Nomor 1 Tahun 1974 Tentang Perkawinan oleh Tim BIP. Diterbitkan oleh Bhuana Ilmu Populer, 2017, Jakarta. 